\title{
KERJA BAKTI SETIAP MASJID DAN INSTANSI
}

\section{(KELURAHAN BONTOTANGNGA KEC.TAMALATEA)}

NAMA : ALIEF ALFHADIN

NIM : 19193770410012

EMAIL : didinsuro7@gmail.com

1. Bentuk Kegiatan

- Membersihkan masjid

- Penyemprotan desinfektan

2. Lokasi

- Masjid Besar Nurul Jihad Kelurahan Bontotangnga Kec. Tamalatea

3. Hari Tanggal Dan Waktu

- Jumat, 25 september 2020 pukul 08 : 00

4. Peserta Yang Dilibatkan

- $\quad$ Mahasiswa KKLP YAPTI JENEPONTO

5. Alasan Yang Diadakannya

- Setelah observasi lapangan kami melihat bangunan masjid yang rutin di pakai shalat jumat dan dari sinilah kami berinisiatif melakukan kegiatan ini. Apalagi saat sekarang ini kita sedang dalam masa pandemic covid 19.

6. Untuk Tujuan Dan Manfaat

- Kami mengadakan program kerja ini, agar masyarakat yang berada disekitar masjid kelurahan bontotangnga merasakan kenyamanan saat beribadah.

- Kegiatan ini adalah kegiatan yang sangat positif karena selain mengingat kebersihan sebagian dari iman kita juga melakukan pendekatan terhadap masyarakat setempat.

7. Deskripsi Kegiatan

- Pada kegiatan ini kami membagi diri untuk saling mengambil perang dalam membersihkan masjid diantaranya menyapu, membersihkan jendela, membersihkan tempat wudhu, dan toilet. Setelah semua selesai maka yang terakhir yaitu menyemprotkan cairan desinfektan, di area tempat wudhu. 
A. INSTANSI

1. Bentuk Kegiatan

- Kerja Bakti Di Setiap Masjid Dan Instansi

2. Lokasi

- Kantor Lurah Bontotangnga

- Kantor Kecamatan

- Masjid di Kel.Bontotangnga

3. Hari Tanggal Dan Waktu

- $\quad$ Hari Minggu, 11-Oktober-2020/ Pukul 08. 00-11.00 Wita

4. Peserta Yang Dilibatkan

- Mahasiswa KKLP YAPTI JENEPONTO

- Anggota Koramil, dan

- Staf Kecamatan

5. Alasan Yang Diadakannya

- Instansi lebih bersih dan mendapat nilai plus dari beberapa instansi dan masyarakat yang melihat.

6. Tujuan Dan Manfaat

- Untuk meningkatkan pentingnya kebersihan lingkungan, sehingga suasana dikantor atau tempat kerja akan terasa nyaman dan terpelihara dengan baik.

7. Deskripsi kegiatan

- Mahasiswa KKLP YAPTI JENEPONTO bersama-sama mengadakan Kerja Bakti pada hari minggu dipagi hari. 